\title{
bcl-2欠損マウスでみられる腎病変は尿管芽由来上皮の bcl-2の発現により改善する
}

\author{
近藤 秀治 ${ }^{* 1} \cdot$ Christine M Sorenson ${ }^{* 2} \cdot$ 須賀 健一 ${ }^{* 1}$ \\ 松浦 里 ${ }^{* 1} \cdot$ 木下ゆき子 ${ }^{* 1} \cdot$ 香美 祥二 ${ }^{* 1}$ \\ (受付日 : 平成21年 8 月11日 採用日 : 平成21年 8 月18日)
}

\section{要旨}

胎児腎藏では，アポトーシス抑制分子 bcl-2は尿管芽 や集合管等に発現し成熟とともにbcl-2の発現は低下す る。bcl-2欠損マウスの胎児腎臓では後腎間葉の著明な アポトーシスと尿管芽の分岐の減少により低形成腎をき たし成熟腎で腎囊胞が形成される。bcl-2欠損マウスの 尿管芽と集合管上皮に選択的に bcl-2を発現させること により腎藏の重量や容積か増大し低形成腎は改善した。 また, 囊胞形成や系球体の肥大は軽減しネフロン数も増 加した。bcl-2欠損マウスでみられる亢進したアポトー シスや細胞増殖の程度も改善した。以上から，bcl-2の 尿管芽と集合管上皮への発現により，ネフロン数が増加 し bcl-2欠損マウスでみられる腎低形成や囊胞腎は部分 的に改善する。

\section{序言}

マウスの腎発生 (後腎) では胎生11日 (E11) 頃に後 腎間葉細胞由来のシグナルにより，ウォルフ管から尿管 芽が出芽し後腎間葉細胞塊に貫入する。尿管芽と後腎間 葉細胞の相互作用により，尿管芽は分岐を繰り返す。ま

*1德島大学大学院ヘルスバイオサイエンス研究部小児医学分野 (†770-8503 徳島市蔵本町 3丁目18-15)

Improvement of renal hypoplasia and cystic dysplasia with re-expression of bcl-2 in the ureteric bud/collecting duct of bcl-2 -/- mice

Shuji Kondo*1, Christine M Sorenson*2, Kenichi Suga*1, Sato Matsuura ${ }^{* 1}$, Yukiko Kinoshita*1 ${ }^{*}$ Shoji Kagami ${ }^{* 1}$

${ }^{* 1}$ Department of Pediatrics, The Institute of Health Bioscience, the University of Tokushima Graduate School

${ }^{*}$ Department of Pediatrics, University of Wisconsin-Madison
た，後腎間葉細胞は凝集し vesicle を形成，comma-，Sshaped body へと変化し上皮へと分化する。S-shaped body の遠位部は尿細管へと分化し集合管を形成する尿 管芽と融合する。一方，S-shaped body の近位部は血管 新生や脈管形成による系球体毛細血管の形成と系球体上 皮細胞やボウマン囊上皮細胞への分化を通じて成熟系球 体へと構筑されていく。マウスでは，ヒトとは異なり出 生後も腎表層部を中心にネフロンの形成が行われてい $る^{11}$ 。

アポトーシスとは, 多細胞生物をより良い状態に保つ ために積極的に引き起こされるプログラムされた細胞死 であり藏器発生や形態形成などさまざまな生理的状態で みられる2)。アポトーシスは尿管芽の分岐やネフロン形 成においても重要な役割を果たしている。bcl-2は， Tsujimoto らによって悪性リンパ腫細胞から発見された 分子で, アポトーシスを強力に抑える作用を有する3)。 1993年にbcl-2欠損マウスが作製されて以来，体内の 種々の細胞において bcl-2が細胞の長期生存，特に腎藏 の発生に必要な遺伝子であることが証明された4)。胎児 腎藏では bcl-2は尿管芽および尿管芽由来の上皮と後腎 間葉細胞の凝集部位で発現し，成熟とともに光の発現は 低下している5)。Nagata らやわれわれの解析により， bcl-2欠損マウスでは低形成腎と腎囊胞形成/異形成腎 を呈することが明らかになっている67)。bcl-2欠損マウ スのE12頃の腎藏では，後腎間葉の著明なアポトーシス と尿管芽の分岐が減少している一方, 成熟腎では, 腎囊 胞形成が顕著となり，病変部位では, アポトーシスと細

Key words : bcl-2

腎発生

噮胞腎

低形成腎

アポトーシス 
糸球体数 $/$ 矢状断

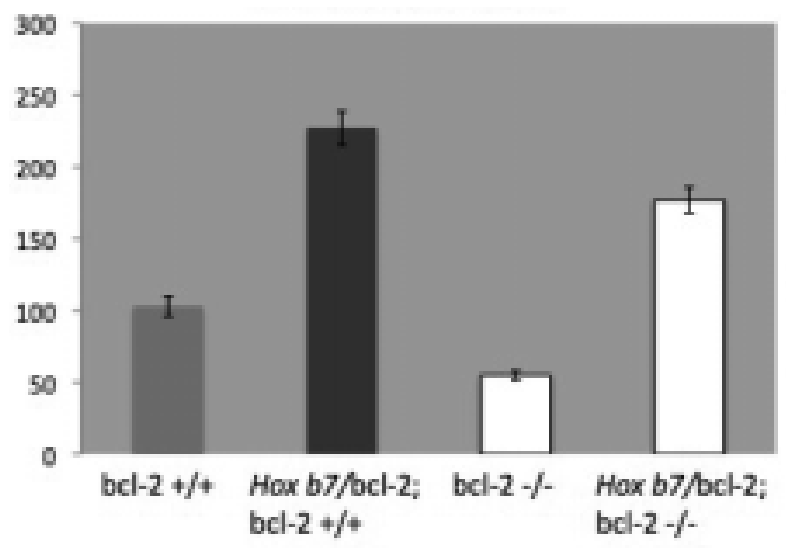

糸球体体積 $\left(\times 10^{-4}\right)$

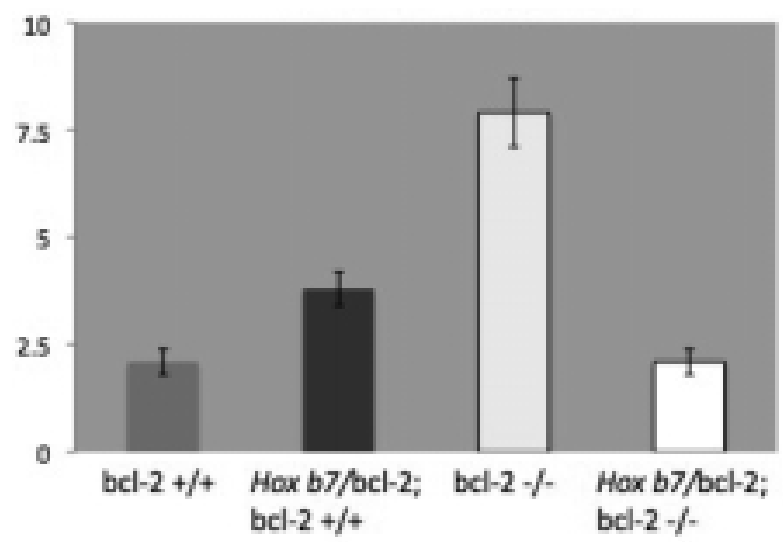

系球体数 /腎臓

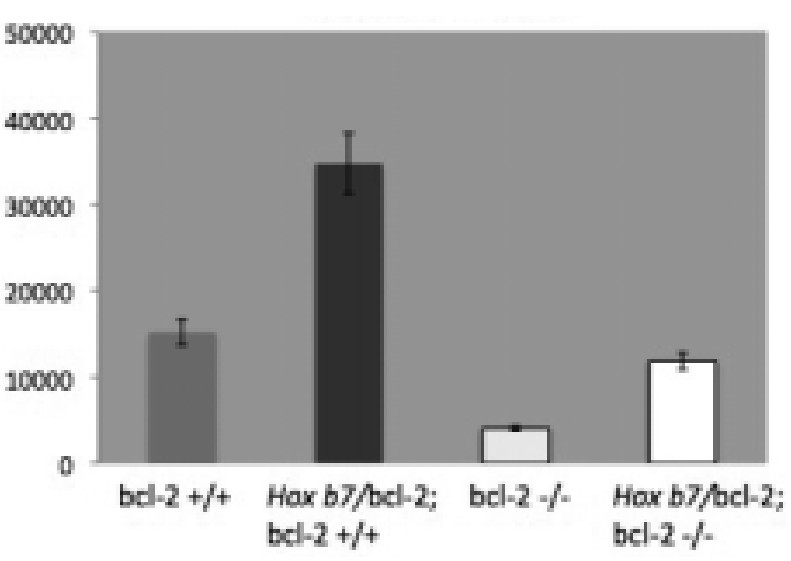

系球体細胞数

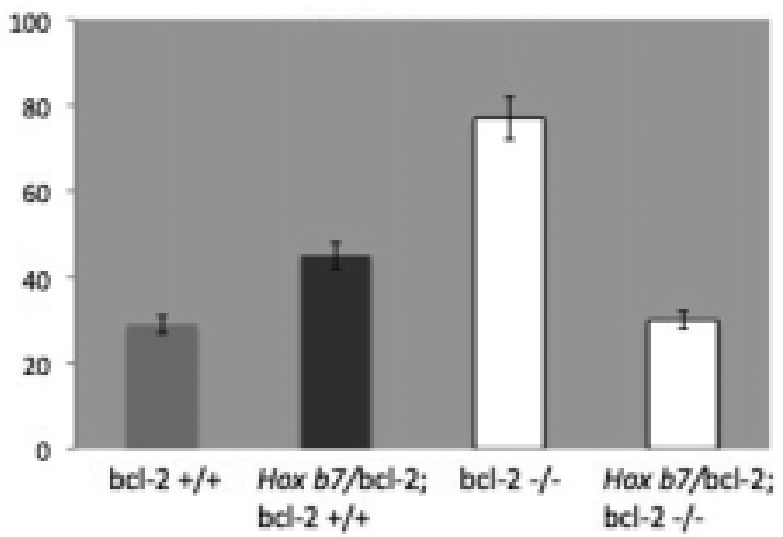

図 bcl-2欠損マウスの系球体数, 系球体体積, 系球体細胞数

胞増殖が六進している。これらの病変形成にbcl-2が果 たす役割を明らかにするために，bcl-2欠損マウスの尿 管芽由来上皮に bcl-2を発現させ腎発生異常が改善し得 るかを評価した。ここでは, 光の研究成果のまとめと bcl-2の腎発生での役割を検討したので概説したい。

$$
\text { 方法 }
$$

1) Hoxb 7 /GFP トランスジェニックマウスの腎藏で は，GFP が尿管芽と尿管芽由来上皮細胞（集合管） に選択的に検出される8)。従って，Hox b 7 の promoter の下流に bcl-2のcDNA を組み込み, bcl-2欠損マウス の尿管芽と尿管芽由来上皮細胞に bcl-2を選択的に発 現するトランスジェニックマウスを作成した。

2 ) トランスジェニックマウスのP25の腎組織で, bcl-2 の発現の有無と光の局在についてWestern Blot と免 疫二重染色で調べた。HE 染色標本で組織所見を検討 した。さらにBertram らの測定法により系球体数を 測定した
3 ) 新生仔 (P O ) および成熟マウス (P25) の腎藏で の Ki-67, PAX 2, cleaved caspase 3 の発現を免疫染 色で，アポトーシスをTUNEL assay で検討した。

4 ) 腎囊胞形成時の増殖シグナルに関連する分子 protein tyrosine phosphatase 1B (PTP 1B) の発現と局 在を検討した。Dolichos biflorus agglutinin (DBA) に よる whole-mount 染色を行い尿管芽の分岐 (分岐点 と分岐先端の数) を評価した。

成 績

1 ．尿管芽と集合管にbcr 2を発現するトランスジェ ニックマウスの作成

Hox b 7 の promoter の下流に bcl-2のCDNA を組み込 み，光の遺伝子の中で最も発現レベルの高いfounder を 用いてトランスジェニックマウスを作成した。P25のト ランスジェニックマウスの腎藏に bcl-2が強く発現する ことをwestern blotにて確認した。さらに, bcl-2の発 現が尿管芽と尿管芽由来上皮細胞（集合管）に選択的に 
発現することをDBA と bcl-2の二重染色で確かめた。 また，光の他の部位ではbcl-2の発現はみられなかっ た。

2 . 腎囊胞や低形成腎における bcr 2の役割

bcl-2欠損マウスのP25の腎藏では, 光の重量や容積 の減少がみられ囊胞形成を伴う低形成腎を呈するが，卜 ランスジェニックマウスでは bcl-2欠損マウスと比較し て腎藏の重量や容積が増大し囊胞形成は減少した。ま た, bcl-2欠損マウスでのネフロン数減少に伴う代償変 化としての系球体肥大はトランスジェニックマウスで軽 減した。実際に系球体数や体積，系球体細胞数を計測し たところ，bcl-2欠損マウスでは系球体数の低下と系球 体体積と系球体細胞数の増加がみられたが , トランス ジェニックマウスでは, 系球体数が増加し系球体体積は bcl-2欠損マウスと比較して軽減した (図)。従って， bcl-2はネフロンの形成に関与し，ネフロン数の維持に 関係していると考えられた。

次に, bcl-2欠損マウスの囊胞形成部位では, 穴進し たアポトーシス (TUNEL 陽性細胞数の増加) や細胞増 殖 ( $\mathrm{Ki}-67$ 陽性細胞数の増加) が認められた。一方，卜 ランスジェニックマウスでは䝴胞形成の抑制に伴い，ア ア ポトーシスや細胞増殖は bcl-2陽性コントロールマウス のレベルに改善した。従って, bcl-2欠損マウスの囊胞 形成部位では, 細胞増殖やアポトーシス等を誘導するシ グナル伝達に何らかの変化が起こっている可能性があ る。

PTP 1 B は細胞接着部位で細胞増殖に関連するリン酸 化シグナル分子を脱リン酸化する作用を持つ。われわれ は, bcl-2欠損マウスの腎囊胞形成において細胞接着斑 キナーゼ (FAK)，パキシリン, Erk1/2等のリン酸化シ グナルが持続え進し, リン酸化シグナルを制御調整する PTP 1 B の活性型 p42の低下や細胞内局在の変化を報告 しており ${ }^{10)-12)}$, 光の局在と発現レベルおよび活性化は, 腎発生および成熟だけでなく蓑胞の形成時にも役割を果 たしている可能性がある ${ }^{10)}$ 。今回の検討でも bcl-2欠損 マウスでは囊胞上皮の細胞周囲ではなく細胞質全体に PTP 1 B の強い発現がみられ活性型 p42の発現の低下が みられた。bcl-2陽性コントロールマウスとトランス ジェニックマウスでPTP 1 B は尿細管細胞周囲 (細胞接 着部位)に局在し 550 と 42 は同レベルの発現であっ た。このことから, bcl-2欠損マウスの病変部ではPTP $1 \mathrm{~B}$ が適切に機能せず細胞増殖のリン酸化シグナルが持 続し，一方，トランスジェニックマウスでは適切にシグ ナル伝達の制御が行われていると考えられた。 3.bcr 2とネフロン形成および尿管芽分岐

腎成熟における bcl-2の細胞増殖やアポトーシスへの 影響を検討するため，ネフロン形成部位 (P0)での PAX 2 ，Ki-67，活性型Caspase $3 の$ 発現を調べた。 bcl-2欠損マウスではPAX 2 や Ki-67のネフロン形成部 位での発現とネフロン形成部位の深さは減少していた が，トランスジェニックマウスでは改善していた。bcl2欠損マウスでみられる六進したアポトーシスもトラン スジェニックマウスで抑制された。

ネフロン数は尿管芽分岐数に影響されると考えられて おり，われわれも bcl-2欠損マウスでは尿管芽の分岐数 が減少していることを報告してきた ${ }^{13)}$ 。今回の研究で卜 ランスジェニックマウスではネフロン数か増加していた ことから，bcl-2を尿管芽細胞に選択的に発現させるこ とにより bcl-2 (欠損マウス) で減少した尿管芽分岐数 が改善するかをE12の腎藏を用いて whole-mount 染色 を施行し評価した。トランスジェニックマウスでは尿管 芽分岐数が改善していた。以上から bcl-2は，尿管芽の 分岐に影響してネフロン数を規定する役割があると考え られた。

\section{考察}

今回の研究をまとめると以下の通りである。bcl-2欠 損マウスの尿管芽と集合管上皮に選択的にbcl-2を発現 させることにより腎藏の重量や容積か増大し低形成腎は 改善した。また, 囊胞形成や系球体の肥大は軽減しネフ ロン数も増加した。bcl-2欠損マウスでみられるえ進し たアポトーシスや細胞増殖の程度も改善した。

bcl-2は腎藏の発生で重要な役割を果たしている。 bcl-2を欠損しても腎藏は発生するが, アポトーシスは 腎発生早期より起こっており，結果として生後に低形成 腎や囊胞腎を呈するようになる。今回の研究では, bcl-2 を選択的に尿管芽と尿管芽由来集合管上皮に発現させる ことで bcl-2が尿管芽の分岐に影響していることが明ら かとなった。従って, bcl-2のトランスジェニックマウ スでは, 尿管芽の分岐数が増加することによりネフロン 数か増加し, 最終的に腎全体の容積や重量が改善したも のと考えられる。興味深いことに，PAX 2 遺伝子異常の 腎コボローマ症候群では尿管芽分岐およびネフロン数減 少に伴う腎低形成がみられ腎機能低下へと進行するが， Goodyer らは, PAX 2 欠損マウスを用いてPAX 2 の promotor の下流にbcl-2を組み込み選択的に尿管芽に発現 させた。これにより，アポトーシスは抑制され尿管芽の 分岐数やネフロン数が増加し低形成腎の改善と腎機能低 下の抑制がみられることを示した ${ }^{14)}$ 。現在のところ尿管 
芽が分岐する正確な機序は不明であるが, bcl-2を介し たアポトーシスの制御は尿管芽分岐に重要な影響を与え ている可能性がある。

われわれは，尿管芽細胞を用いた培養実験で，コラー ゲンゲルやマトリゲル内で bcl-2欠損細胞では分岐の形 成が抑制されることを報告した。さらに，この現象に bcl-2欠損による異常な細胞接着や細胞遊走が関与して いることも報告した ${ }^{13)}$ 。従って, $\mathrm{bcl}-2$ が細胞接着機能 にも影響していることが考慮され，bcl-2欠損による細 胞接着や遊走機能の変化が, 今回の研究でみられる尿管 芽の分岐数の変化に影響した可能性がある。

bcl-2の細胞接着への影響は，尿管芽の分岐だけでな く囊胞形成にも関与している可能性がある。光の理由と して, bcl-2欠損マウスの腎囊胞形成部位の上皮細胞で は, FAKやパキシリン等の細胞接着関連蛋白および光 の下流のシグナル蛋白のリン酸化が持続立進しているこ とが挙げられる。特に，腎発生ではbcl-2とパキシリン の結合は重要と考えられている ${ }^{15)}$ 。ADPKDやARPKD 等の囊胞腎でも細胞接着は病態にかかわっているとさ れ，腎囊胞が形成される機序を明らかにする手段の一つ として，bcl-2が関連する細胞接着機構やシグナル調節 を明らかにすることは重要であると思われる ${ }^{16) 。}$

\section{結論}

bcl-2を尿管芽と集合管上皮に選択的に発現させるこ とにより，細胞増殖やアポトーシスの制御を通じて bcl-2欠損マウスでみられる腎低形成や囊胞腎は部分的 に改善する。bcl-2は尿管芽の分岐に影響してネフロン 数を調節し腎藏の発生と成熟に重要な分子であると考え られた。本研究成果の一部は, Developmental Dynamics 誌に報告している17)。

「日本小児腎臓病学会の定める基準に基づく利益に関す る開示事項はありません。」

\section{参考文献}

1 ) Saxen L : Organogenesis of the kidney. New York : Cambridge University Press, 1897.

2 ) Ellis RE, Yuan J, Horvitz RH : Mechanisms and functions of cell death. Annu Rev Cell Biol $7: 663-698,1991$.

3 ) Tsujimto $Y$, Croce $C M$ : Analysis of the structure, transcripts, and protein products of bcl-2, the gene involved in human follicular lymphoma. Proc Natl Acad Sci USA 83:5213-5218, 1986.

4 ) Veis DJ, Sorenson CM, Shutter JR, Korsmeyer SJ : bcl-2deficient mice demonstrate fulminant lymphoid apoptosis, polycystic kidneys, and hypopigmented hair. Cell $75: 229-240$ 1993.

5 ) Veis $D$, Korsmeyer $S$ J : bcl-2 protein expression during murine development Am J Pathol $145: 61-73,1994$.

6 ) Nagata M, Nakauchi H, Nakayama K, Nakayama K, Loh D, Watanabe $T$ : Apoptosis during an early stage of nephrogenesis induces renal hypoplasia in bcl-2-deficient mice. $148: 1601-$ 1611, 1996.

7 ) Sorenson SM, Padanilam BJ, Hammerman MR : Abnormal postpartum renal development and cystogenesis in bcl-2 (-/-) mice. Am J Physiol 271 : F 184-F 193, 1996.

8 ) Srinivas S, Goldberg MR, Watanabe T, D'Agati V, Al-Awqati Q, Constantini $F$ : Expression of green fluorescent protein in the ureteric bud of transgenic mice : a new tool for the analysis of ureteric bud morphogenesis. Dev Genet $24: 241-251,1999$.

9 ) Bertram J F : Counting in the kidney. Kidney Int $59: 792-796$, 2001.

10) Sorenson CM, Sheibani $N$ : Altered regulation of SHP-2 and PTP $1 \mathrm{~B}$ tyrosine phosphatases in cystic kidneys from bcl-2 -/- mice. Am J Physiol 282 : F 442-F 450, 2002.

11) Sorenosn CM, Sheinbani N : Focal adhesion kinase, paxillin, and bcl-2 : analysis of expression, phosphorylation, and association during morphogenesis. Dev Dyn 215 : 371-382, 1999.

12) Sorenosn CM, Sheinbani $N$ : Sustained activation of MAPK/ERKs signaling pathway in cystic kidneys from bcl-2 -/- mice. Am J Physiol 283 : F 1085-1090, 2002.

13) Sheibani $N$, Scheef EA, Dimaio $T$, Wang $Y$, Kondo S, Sorenson $\mathrm{CM}: \mathrm{bcl}-2$ expression modulates cell adhesion and migration promoting branching of ureteric bud cells. J Cell Physiol 210: 616-625, 2007.

14) Dziarmaga A, Eccles $M$, Goodyer $P$ : Suppression of ureteric bud apoptosis rescues nephron endowment and adult renal function in Pax2 mutant mice. J Am Soc Nephrol $17: 1568-1575$, 2006.

15) Sorenson $\mathrm{CM}$ : Interaction of $\mathrm{bcl}-2$ with paxillin through its $\mathrm{BH} 4$ domain is important during ureteric bud branching. J Biol Chem 279 : 11368-11374, 2004.

16) Calvet J P : Polycystic kidney disease : primary extracellular matrix abnormality or defective cellular differentiation? Kidney Int $43: 101-108,1993$.

17) Kondo S, Oakes MG, Sorenson CM : Rescue of renal hypoplasia and cystic dysplasia in bcl-2 -/- mice expressing bcl-2 in ureteric bud derived epithelia. Dev Dyn 237 : 2450-2359, 2008. 
日児腎誌 Vol 22 No 2

Improvement of renal hypoplasia and cystic dysplasia with re-expression of

bcl-2 in the ureteric bud/collecting duct of bcl-2 -/- mice

${ }^{*}$ Department of Pediatrics, The Institute of Health Bioscience, the University of Tokushima Graduate School

${ }^{*}$ Department of Pediatrics, University of Wisconsin-Madison

Shuji Kondo*1, Christine M Sorenson ${ }^{* 2}$, Kenichi Suga*1,

Sato Matsuura*1, Yukiko Kinoshita*1, Shoji Kagami ${ }^{* 1}$

$\mathrm{Bcl}-2$ is the founding member of a family of proteins that influence apoptosis. Loss of bcl-2 results in renal hypoplasia/cystic dysplasia at birth. In this review, we show that re-expression of bcl-2 in the ureteric bud/collecting duct resulted in increased nephron numbers partially rescuing renal hypoplasia/cystic dysplasia in bcl-2 -/- mice.

Key words : bcl-2, renal development, renal hypoplasia, cystic dysplasia, apoptosis 